\title{
Fikcjogramy. Elementy przemian literatury współczesnej
}

\author{
Arkadiusz Żychliński
}

TEKSTY DRUGIE 2017, NR 1, S. 187-198

DOI: 10.18318/td.2017.1.15

La literatura no es agotable, por la suficiente y simple razón de que un solo libro no lo es. El libro no es un ente incomunicado: es una relación, es un eje de innumerables relaciones. Una literatura difiere de otra, ulterior o anterior, menos por el texto que por la manera de ser leída: si me fuera otorgado leer cualquier página actual - ésta, por ejemplo - como la leerán el año dos mil, yo sabría cómo será la literatura del año dos mil. ${ }^{1}$

Jorge Luis Borges

1 Słowa Borgesa, jednego z najbardziej przenikliwych - choć nielicencjonowanych - teoretyków literatury minionego wieku, mogą być użytecznym kołem zamachowym każdej zamyślonej jak w tytule refleksji. J.L. Borges Nota sobre (hacia) Barnard Shaw (1951), w: tegoż, Obras completas, vol. II, Círculo de Lectores, Barcelona 1992, s. 341. Por. J.L. Borges Notatka o Bernardzie Shaw, w: tegoż Dalsze dociekania, przeł. A. Sobol-Jurczykowski, Prószyński i S-ka, Warszawa 1999, s. 230: "Literatury nie da się wyczerpać z tego wystarczającego i prostego powodu, że nie da się wyczerpać ani jednej książki. Książka nie jest czymś izolowanym: jest relacją, jest osią niezliczonych relacji. Jedna literatura różni się od drugiej, późniejszej lub wcześniejszej, nie tyle ze względu na tekst, ile raczej ze względu na sposób, w jaki jest czytana: gdyby dane mi było przeczytać jakąkolwiek współczesną stronicę - tę, na przykład - takjak będą ją czytać w roku dwutysięcznym, wiedziałbym, jaka będzie literatura w roku dwutysięcznym".

Arkadiusz Żychliński (1976) - filolog, tłumacz, komparatysta. Profesor w Instytucie Filologii Germańskiej UAM oraz członek zespołu Pracowni Pytań Granicznych w tej uczelni. Autor książek Unterwegs zu einem Denker (2006), Wielkie nadzieje idalsze rozważania (2013), Laboratorium antropofikcji (2014), współredaktor kilku zbiorów interwencji krytycznych poświęconych m.in. Cervantesowi, Kafce, Pessoi i Bolaño. Kontakt: zychlin@amu. edu.pl 
1. Czy w obrębie przeobrażeń współczesnych fikcji literackich, oto pytanie, jakie sobie stawiam, da się dostrzec, przekładając szereg partykularnych perspektyw na spojrzenie ogarniające większą całość oraz ukazujące wzajemne przenikanie i zazębianie impulsów auratycznych i twórczych, jakiś określony wzór, w jaki zdają się układać pojedyncze ślady transformacji, co pozwoliłoby z kolei wykreślić konturowy diagram literackich przemian współczesności? Moja tentatywna odpowiedź jest pozytywna, stąd też doraźnym celem tego szkicu jest właśnie relacja z próby uchwycenia - i prezentacja w maksymalistycznym stężeniu pojęciowym - krystalizujących się na naszych oczach elementów (ewolucyjnych) przemian literatury współczesnej². Wstępne uściślenia, które jedynie wzmiankuję bez komentarza, ponieważ tenże znacznie przekroczyłby wskazane tu ramy, dotyczą zawężenia umownego obszaru analizowanej współczesności przede wszystkim do ostatniego ćwierćwiecza, wzięcia w nawias rastrów narodowo-językowych i skupienia uwagi na literaturze wartościowej artystycznie. Poza tym będą mnie interesować nie koncentracyjne dominanty tematyczne (np. dociążona nierzadko wartościową intencją emancypacyjną postępująca inkluzja podmiotów nie tylko ludzkich z rozmaitych przyczyn tymczasem wspólnotowo wykluczonych) i nie zmiany istotne z socjologicznoliterackiego punktu widzenia (w rodzaju silnej dyseminacji pola literackiego, którego przejściowe centrum może być wszędzie, a trwałego środka nie ma nigdzie), lecz raczej nieco rzadziej omawiane tendencje formalnoliterackie, które intensywnie oddziałują obecnie w przestrzeni literackiego fikcjotwórstwa, oraz ich możliwe konsekwencje recepcyjne, w tym również implikacje owych przemian dla metod i praktyk "literaturoznawstwa stosowanego".

2. Zaznaczę ponadto gwoli ścisłości, że prezentując poniższe elementy przemian literatury współczesnej, wydaję się faworyzować zwłaszcza powieść, postponując formy literackie innego rodzaju. Ze względu na pożądany minimalizm ograniczę się tu do konstatacji, że jedną z flankowych tendencji współczesnej literatury jest hybrydyzacja czy intereferencyjność gatunkowa stawiająca pod znakiem zapytania przydatność tradycyjnych, także podstawowych kategorii genologicznych. Gatunkiem obecnie dominującym wydaje się wprawdzie w powszechnym odczuciu właśnie powieść, jednak

2 Nieco inaczej rozkładając akcenty - wychodząc od problematyzacji pojęcia "postępu" w twórczości literackiej - piszę o tym zagadnieniu także w szkicu Zerwanie i ciągłość, czyli o postępie, w: W. Charchalis, A. Żychliński (red.) Wieczna krucjata. Szkice o „Don Kichocie”, Wydawnictwo Naukowe UAM, Poznań 2016, s. 129-156. 
w słuszniejszym, jak sądzę, przekonaniu także znacznej części twórców chodzi raczej o dominację, mówiąc ogólniej, „prozy nieokreślonego rodzaju”, którą przenikają, tak to nazwijmy, momenty prozatorskie i momenty poetyc$\mathrm{kie}^{4}$. Mówiąc zatem o przemianach literatury współczesnej, myślę o zauważalnych zmianach w obrębie owej prozy nieokreślonego rodzaju.

3. Uwzględniając powyższe, stawiam tezę, że zasadniczą poetologiczną i formalnoliteracką dominantą literatury współczesnej jest implikowana kontrafikcyjność, że zatem, innymi słowy, punktem wyjścia badania przemian współczesnych fikcji literackich można uczynić zauważalny deklaratywny odwrót od tychże. Zgoda na taki stan rzeczy albo próba przeciwstawienia się mu formatują współczesną krzywą postępu, zakładając stosunkowo niekontrowersyjnie, że „sztuka postępuje naprzód tylko poprzez dysonanse (l'art ne progresse que par des dissonances) ${ }^{\prime \prime}$. Dysonans charakterystyczny dla literatury współczesnej, zarazem główna metatendencja, to zwarcie będące następstwem przemian ogólnego nastawienia względem twórczości literackiej: jeśli fikcyjność uznalibyśmy za konceptualne centrum fikcji literackich, to moglibyśmy podzielić je (z punktu widzenia operacyjnej użyteczności) na fikcje centrypetalne i fikcje centryfugalne, czyli fikcje intencjonalnie zdążające czy skierowane ku fikcyjności i fikcje intencjonalnie zdążające czy skierowane przeciw fikcyjności, albo, mówiąc prościej, fikcje afirmujące i eksponujące swoją fikcyjność i fikcje swoją fikcyjność kwestionujące i kamuflujące. Różnicę wyznacza w tym cięciu deklarowane podejście do fikcjotwórstwa jako takiego: fikcje centrypetalne (dośrodkowe) koncentrują się wokół fikcji, zmyślonej opowieści, fikcje centryfugalne (odśrodkowe) przyjmują strategię antyfikcyjnej mimikry, podając się za nie-fikcje ${ }^{6}$.

3 W.G. Sebald „Auf ungeheuer dünnem Eis". Gespräche 1971 bis 2001, hg. von T. Hoffmann, Fischer, Frankfurt am Main 2011, s. 85, 199.

4 Piszę o tym więcej w książce Laboratorium antropofikcji. Dociekania filologiczne, Warszawa-Poznań, Wydawnictwo IBL PAN, WN UAM, 2014, s. 333 i n.

5 A. Thibaudet Historia literatury francuskiej. Od Rewolucji Francuskiej do lat trzydziestych XX wieku, przeł. J. Guze, PWN, Warszawa 1997, s. 322. Oryg. A. Thibaudet Histoire de la littérature française de 1789 à nos jours, Stock, Paris 1936, s. 339.

6 Wymownym ilustratywnym przykładem tego rodzaju kontrastu w obrębie najgłośniej dziś bodaj dyskutowanych (w zachodniej przestrzeni krytycznoliterackiej) projektów literackich mogłoby być przeciwstawienie (centryfugalnej) heksalogii Min kamp (Oktober, Oslo 2009-2011) Karla Ove Knausgårda (centrypetalnej) tetralogii L'amica geniale (E/O, Roma 2011-2014) Eleny Ferrante. Punkt wyjścia obydwu zamysłów jest zbieżny: opisać (jedno konkretne) życie w jego zwyczajności, realizacja techniczna także dość podobna (trącącą narracyjną myszką prosto- 
Można oczywiście zapytać zasadnie, czy tego rodzaju metatendencja nie nosi aby znamion uniwersalności: ostatecznie chwyt uwiarygodniania fikcji przez werbalne zakwestionowanie jej potencjalnie fikcyjnego statusu nie jest jako taki niczym szczególnie nowym. To prawda, aczkolwiek oprócz bezprecedensowej dziś skali napięcia wewnątrz pola literackiego strategicznej różnicy upatruję także w stopniowej deflacji defikcjonalizujących metakomunikatów, które początkowo recypowane są wprawdzie najczęściej zgodnie z intencją, czyli niediegetycznie, z czasem jednak nieuchronnie stają się elementem diegezy. Wydaje się, że nader intensywnie eksplorowana obecnie autofikcyjność wyznacza w tej mierze pewną skrajną pozycję, której dalsze przekroczenie trudno sobie wyobrazić.

Spróbujmy doprecyzować powyższe rozpoznanie: od samego początku zorganizowanej fabulacji trwają rokowania dotyczące właściwych danemu interwałowi dziejów warunków ratyfikacji paktu fikcji, którego istota zasadza się z punktu widzenia twórcy na opowiedzeniu historii wykreowanej siłą imaginacji, zaś z punktu widzenia odbiorcy na chwilowym zawieszeniu niewiary i zgodzie na zanurzenie się w owej wirtualnej rzeczywistości (przy czym rzecz wcale niekoniecznie w naiwnym utożsamieniu, lecz raczej w potencjalnym zwielokrotnieniu). Gwoli uwiarygodnienia opowieści w przeszłości stosowano niekiedy chwyt polegający na punktowej wejściowej ekspozycji autora, tym efektywniej już po chwili znikającego: pojawiał się on na początku jedynie po to, by dyskretnie dać do zrozumienia, że co do opowiadanej historii, której gwarantem prawdziwości będą stosownie wzmiankowane źródła, przypadła mu do odegrania jedynie służebna rola transparentnego medium. Kiedy jednak dziś Jerzy Pilch rozpoczyna swoją powieść od wprowadzenia na scenę rękopisu znalezionego w „lewym, mocno sfatygowanym narciarskim

linijna linearność), jednak deklaratywny stosunek do fikcyjności własnych fikcji odmienny: podczas gdy Knausgård świadomie podważa domniemaną czy nieuniknioną fikcyjność każdej próby opisania siebie, obstając przy referencyjnej prawdziwości własnego zapisu, Ferrante, począwszy od decyzji pisania pod pseudonimem (z jego niedawnym ujawnieniem łączy się kontrowersja interesująca także z teoretycznego punktu widzenia), demonstracyjnie podważa istotność roztrząsania pytań w rodzaju: „czy to rzeczywiście przydarzyło się mnie czy też raczej pewnej figurze mojego ja?". Z tym pozornie mało istotnym inicjalnym wyborem wiążą się nie tylko spekulatywne konsekwencje: z czysto pragmatycznego punktu widzenia łatwo skontrastować wizerunkową (nad)obecność Norwega w sferze publicznej z zupełną nieobecnością Włoszki. Jak obydwie strategie reprezentacji przekładają się na niuanse recepcji - abstrahując do makrosukcesu obojga autorów - pozostawiam tu bez bardziej wnikliwego komentarza (aczkolwiek pośrednio wracam jeszcze do tego w dalszej części wywodu) jako temat wart osobnego omówienia. 
bucie, but leżał w kamienicy na Hożej, na schodach, na wysokości drugiego piętra"', to oczywiście nawet niewyrobiony czytelnik ma wprawdzie może raczej bliżej niesprecyzowane, niemniej silne poczucie jedynie już ironicznej introdukcji.

W związku z pogłębiającym się niemal od początku XX wieku kryzysem legitymizacji fikcji literackich - jego istotę oddaje coraz bardziej natarczywe pytanie o zasadność percepcji umyślnego zmyślenia - możemy wyróżnić dwie główne fazy zorganizowanego odśrodkowo poetologicznego odporu. Amplitudę pierwszej wyznacza powstanie niefikcyjnej fikcji, czyli powieści dokumentalnej, którą możemy określić ogólnym mianem panfikcji, jako że proklamuje ona swoją ontyczną prawdziwość bez eksponowania tożsamego z narratorem autora. „Wielkim osiągnięciem Z zimną krwią (powieści o podtytule, jak pamiętamy, Prawdziwa opowieść o wielokrotnym morderstwie i jego konsekwencjach, A.Ż.) jest to, mówi w rozmowie Truman Capote, „że ja sam nie pojawiam się w niej ani razu. Nie ma tam ani jednego «ja»"8. Kolejnym punktem kulminacyjnym są autofikcje, wraz z którymi na diegetycznej scenie pojawia się autofikcyjne „ja”, któremu jak dotąd dość skutecznie udaje się przechodzić test niediegetyczności. Właśnie wprowadzenie własnego tekstualnego awatara okazuje się chwytem najskuteczniej obecnie z recepcyjnego punktu widzenia quasi-defikcjonalizującym fikcję, aby umożliwić tym samym osobliwie oksymoroniczną operację immersji poprzez emersję ${ }^{9}$, czyli zanurzenia w przestrzeni stworzonej przez autora dzięki silnie zinterioryzowanemu przeświadczeniu, że jest to przestrzeń jedynie przezeń odtworzona.

W obrębie tak ujmowanych fikcji centryfugalnych - czyli najogólniej „literatury (naocznych) świadków” (veni, vidi, scribi), autorstwa pisarzy tak różnych jak Javier Cercas, Laurent Binet, David Shields, Emmanuel Carrère, Eduardo Halfon, Tomas Espedal, Alejandro Zambra, David Wagner, Per Olov Enquist, Frédéric Beigbeder, Karl Ove Knausgård czy Lukas Bärfuss, by wymienić choćby kilku - pojawia się z kolei gama wyraźnie rozpoznawalnych dalszych chwytów, konstytuujących część (nader interesującej) współczesnej beletrystyki. Służą one wzmacnianiu - stworzonej już inicjalnym wyborem centryfugalnym - iluzji epistemologicznej niezapośredniczoności. Chodzi

7 J. Pilch Zuza albo czas oddalenia, Wydawnictwo Literackie, Kraków 2015, s. 5.

8 L. Grobel Truman Capote. Rozmowy, przeł. W. Łyś, Axis Mundi, Warszawa 2014, s. 136.

9 Korzystam z pojęcia emersji zaproponowanego przez Piotra Kubińskiego: „Elementy [...], które przeszkadzają w osiągnięciu immersji, nazywam emersyjnymi". Por. tegoż Gry wideo. Zarys poetyki, Universitas, Kraków 2016, s. 66. 
zwłaszcza, po pierwsze, o (swoiste) „nicowanie” fikcji: włączanie w ich obręb elementów wcześniej raczej skrzętnie skrywanych, a odsłaniających kulisy ich powstawania czy tworzenia. André Gide publikuje powieść Fatszerze w roku 1925, rok później ukazują się natomiast - osobno - dotyczące pracy twórczej notatki pod tytułem Dziennik «Fałszerzy», Thomas Mann w roku 1947 wydaje Doktora Faustusa, zaś w 1949 dodaje doń komentujący szkic Jak powstat «Doktor Faustus» etc. pp. Z kolei liczni współcześni pisarze (np. wszyscy wyżej wzmiankowani) czynią proces powstawania fikcji literackich, które w lekturze uruchamia w swojej wyobraźni każdorazowy czytelnik, nie jak wcześniej zaczynem ewentualnego aneksu, lecz konstytutywnym wręcz elementem składowym właściwego projektu. „Mimo kolejnych prób nigdy nie zdołałem przebrnąć przez Pamiętniki Hadriana", pisze Emmanuel Carrère w ostatniej powieści, „za to bardzo lubię zapiski robocze załączone do tej powieści przez Marguerite Yourcenar, która poświęciła jej dwadzieścia lat życia. Jako człowiek współczesny przedkładam szkic nad wielki obraz [En bon moderne, je préfère l'esquisse au grand tableau]"10. W jednej z wcześniejszych książek notuje natomiast w trybie autopoetologicznym: „Większość filmów dokumentalnych robi się tak, jakby ekipy przy tym nie było. Należałoby zrobić coś wręcz przeciwnego [Il faudra faire exactement le contraire], tematem byłoby nie miasto [le sujet ce ne serait pas la ville], ale nasz pobyt w mieście (mais notre séjour dans la ville), reakcje wywołane przez nasz pobyt [les réactions que suscite notre séjour]"11. Nie trzeba podkreślać wielorakiej symptomatyczności obydwu tych stwierdzeń.

Po drugie zaś, idzie o swoiście ukonstytuowaną interaktywną auktorialną autoreferencyjność performatywną ${ }^{12}$, czyli inscenizowanie w przestrzeni fikcji literackiej własnej autobiografii, a następnie nadawanie jej mocy performatywnej przez wprzężenie jej w sieć społecznej interaktywności. Należy w tym względzie zauważyć, że o ile (autofikcyjna) literatura konfesyjno-memuarystyczna jest gatunkiem ze znaczną przeszłością, o tyle dopiero współczesne możliwości techniczne nadają tej formie performatywnego rozmachu (zdjęcie autora nie tylko wychyla się z okładek książek, lecz także sam pisarz,

10 E. Carrère Królestwo (2014), przeł. K. Arustowicz, Wydawnictwo Literackie, Kraków 2016, s. 315. Oryg. E. Carrère La Royaume, POL, Paris 2014, s. 382.

E. Carrère Powieść rosyjska, przeł. A. Trznadel-Szczepanek, MUZA SA, Warszawa 2008, s. 46. Oryg. E. Carrère Un roman russe, POL, Paris 2007, s. 50.

12 Modyfikuję tu nieco pojęcie zaproponowane przez duńskiego literaturoznawcę Jona Helta Haardera, por. tegoż Performativ biografisme, Gyldendal, København 2014. 
a nierzadko również jego rodzina i bliscy przekonują czytelników w licznych wywiadach o referencyjnej odpowiedniości powieściowych osobowości literackich). „To był eksperyment”, mówi Karl Ove Knausgård, „opublikowałem pierwsze książki, kiedy pisałem następne, równocześnie docierały do mnie już reakcje ludzi, którzy pojawiali się w pierwszym tomie. Granica między literaturą i życiem została czasowo zawieszona. Moje postaci przychodziły do mnie i kłóciły się ze mną"13. Istotnym celem tego chwytu jest inscenizacja wydarzania się referencyjnej prawdy, czyli urealnianie fikcji przez jej bieżące spotęgowanie, skutkujące powstaniem swego rodzaju metaleptycznego tunelu łączącego świat realny ze światem przedstawionym.

Przyczyną, dla której nie biorę odautorskich deklaracji za dobrą monetę i zamiast mówić o nowej niefikcyjnej prozie dokumentalnej zdecydowanie wolę mówić o fikcjach centryfugalnych, jest obecny niemal w każdej wyraźny - zamierzony lub nie, zależnie od samoświadomości twórców - moment rozchwiania i autodekonstrukcji iluzji bezpośredniości. Zarówno wspomniany na wstępie element deklaratywnej kontrafikcyjności, jak i obydwa główne dostrzegalne w jego obrębie chwyty można określić ogólnym mianem „strategii autentyczności”, działających na rzecz intensyfikowania „prawdziwości", jak pojmuje ją dziś znaczna część czytelników, i uznać za odpowiedź na zmiany nastawienia percepcyjnego znacznej części (także wyrobionych) odbiorców, z jednej strony coraz bardziej „zgłodniałych rzeczywistości”, z drugiej poszukujących „wiedzy” $i$,prawdy” poza fikcjami literackimi, z trzeciej mających recepcyjny kłopot z ostentacyjnie hiperrealistycznymi, a zarazem deklaratywnie fikcyjnymi fikcjami.

4. Z tego punktu widzenia kontrafikcyjność jest interesującym - zarazem anachronicznym, jak i paradoksalnie awangardowym (można ją potraktować jako swego rodzaju poetologiczne „berkeleyowskie kopnięcie”) - rysem współczesności na poziomie refleksji teoretycznoliterackiej i frapującym zestawem chwytów na poziomie formalnoliterackim, zarazem jednak emblematem kryzysu na poziomie recepcyjnym. Jeśli bowiem w charakterystycznym skrócie myślowym część wyrobionych czytelników, w tym także zarządzający odnośnym prestiżem prawodawcy pola literackiego, autorów deklaratywnie fikcyjnych fikcji uznaje za autorów nieoferujących już czytelnikom niczego poza elementem relaksacyjnym, względnie dystynktywnym, to odcina tym samym, w zapamiętałym zacięciu jakby wcale tego nie

13 K.O. Knausgård "Ich konnte nicht schreiben, ohne zu verletzen» Ein Gespräch", „Die Literarische Welt" 2015/38. 
zauważając, gałąź, na której znajdziemy nie tylko wszystkich w ogóle twórców fikcji, lecz także autorów pozornie z innego miejsca mówiących czy piszących. O czym świadczy bowiem np. równoczesne zakwestionowanie przez Swietłanę Aleksijewicz istotności fikcji literackich - „Nie mogę pozwalać sobie na zbyt dużo literatury, bo czytelnicy pomyśleliby, że to nie jest prawda, tylko materiał artystyczny" - i równocześnie przyznanie niemal jednym tchem: „Niekiedy do wypowiedzi autora [realnej postaci książki - A.Ż.] zdarza mi się wprowadzić myśl, którą wypowiedział ktoś inny będący w podobnej sytuacji”"14? Stąd sądzę, że podstawowym - czyli fundacyjnym - „trudnym” problemem współczesnego literaturoznawstwa (czy szerzej: fikcjoznawstwa) jest od dawna pojęcie prawdy ${ }^{15}$. Z recepcyjnego - czyli szerzej także: dydaktycznego - punktu widzenia konieczna jest pogłębiona refleksja - której brak przyczynia się do teraźniejszego kryzysu fikcji - nad "trudnym problemem” prawdy fikcji. „Wszyscy trafnie podejrzewamy, że wielka sztuka zawsze jest «prawdziwa» [that all great art is «real»]”, zauważa Peter Brook, ,tylko nie możemy się zgodzić, co to słowo naprawdę oznacza"16. No właśnie: czym jest prawda fikcji?

5. Nie zamierzam szukać odpowiedzi na to pytanie tu i teraz, odnotowuję jednak, że wiele niezwykle nośnych pośrednich odpowiedzi znajdziemy u samoświadomych twórców fikcyjnych fikcji. Właśnie fikcje centryfugalne, pozornie nieco reakcyjne w opisanym wyżej ewolucyjnym zwarciu, bo jawią się jako rzeczywiście mniej widowiskowo innowacyjne (jakkolwiek obserwujemy w ich obrębie np. nader interesujące $\mathrm{z}$ formalnego punktu widzenia ścieranie się tendencji integrystycznej, czyli dążącej do nadania fikcji jak

14 A. Wójcińska Perspektywa mrówki. Rozmowy z reporterami świata, Czarne, Wołowiec 2015, S. 150.

15 W luźnej analogii do rozróżniania zaproponowanego przez Davida Chalmersa, który odróżnia w filozofii umysłu "trudny problem" (the hard problem) od "łatwych problemów" (easy problems). Trudny problem nie tylko, co oczywiste, trudno rozstrzygnąć w obrębie dominującego paradygmatu naukowego, lecz także trudno w ogóle o konsensus co do samego uznania jego istnienia. Por. D. Chalmers Świadomy umysł (1996), przeł. M. Miłkowski, PWN, Warszawa 2010.

16 P. Brook Ruchomy punkt. Czterdzieści lat poszukiwań teatralnych 1946-1987, przeł. E. Guderian-Czaplińska, G. Ziółkowski, Ośrodek Badań Twórczości Jerzego Grotowskiego, Poznań-Wrocław: 2004, S. 101. Oryg. P. Brook The Shifting Point. Theatre, Film, Opera 1946-1987, TCG, New York 1999, s. 83.

17 Zagadnienie to czynię także jedną z tematycznych osi szkicu Jakie fikcje? Czyja wiedza?, w: M. Falkowski (red.) Myślenie dziś. [5], Fundacja na Rzecz Myślenia im. Barbary Skargi, Warszawa 2017 (w druku). 
najbardziej stabilnej struktury, doskonałej pełni, i fluktualistycznej, dającej w efekcie fikcje płynne, kłaczaste, o nieostrych kształtach), okazują się w szerszej perspektywie znacznie bardziej samoświadome, ponieważ to pośród nich powstają wyraziste teoretyczne propozycje swego rodzaju antidotum na kryzysowe toksyny w postaci obecnej podpowierzchniowo w wielu z nich metafikcji, czyli użytecznej praktycznie quasi-teorii (sc. instrukcji obsługi) fikcji. Współczesne metafikcje odróżnia od ich prekursorek z okresu tzw. postmodernizmu przede wszystkim konsekwentnie dyskretne a zarazem nader silne podwójne kodowanie: powieści takie jak Zakochania Javiera Maríasa czy Stodka przynęta Iana McEwana można przeczytać z satysfakcją, nawet zupełnie prześlepiając ich metafikcyjny wymiar, czego nie da się powiedzieć o większości wcześniejszych powieści ostentacyjnie manifestujących swoją literackość drugiego stopnia. Z książek obydwu autorów - wspominanych tu, podobnie jak wszyscy inni, tytułem dobitnego reprezentatywnego przykładu - wyłaniają się wyraziste propozycje konceptualizacji kondycji fikcji jako takich.

Javier Marías, wielokrotnie dający wyraz swemu przekonaniu, że prawdę rzeczywistości można uchwycić jedynie w fikcji, stoi na stanowisku najbardziej może przeciwległym wobec literatury świadectwa: „Tak naprawdę odwieczny cel każdego kronikarza czy świadka [cualquier cronista o superviviente] - opisać to, co się wydarzyło, zdać sprawę z przebiegu wypadków, pozostawić świadectwo faktów, przestępstw i czynów [relatar lo ocurrido, dar cuenta de lo acaecido, dejar constancia de los hechos y delitos y hazañas] - to czcza iluzja i złuda [es una mera ilusión o quimera] czy też, mówiąc ściśle, już sam ten cel, ta fraza są metaforyczne i stanowią część fikcji. «Opisać to, co się wydarzyło [Relatar lo ocurrido]» to rzecz nie do zrealizowania i próżna [es inconcebible y vano], a raczej możliwa tylko przez zmyślenie [es sólo posible como invención]. Podobnie idea dawania świadectwa jest błędna i nie trafił się nigdy żaden świadek, który mógłby sprostać temu zadaniu [También la idea de testimonio es vana y no ha habido testigo que en verdad pudiera cumplir con su cometido]"18. Także Ian McEwan w fabularnie wirtuozerski sposób obnaża iluzję niezapośredniczoności, czyli możność dotarcia do niezmediatyzowanej „autentycznej rzeczywistości” z pominięciem pośrednictwa stosującej sztuczki fikcji, która w ujęciu Maríasa ma kondycję widmową: fikcje - niezależnie od danego medium - mają status nawiedzających nas widm, które, chodząc za nami, nie przestają nas

18 J. Marías Czarne plecy czasu (1998), przeł. T. Pindel, Sonia Draga, Katowice 2014, s. 16. Oryg. J. Marías Negra espalda del tiempo, Debolsillo, Barcelona 2013, s. 18. 
obchodzić. „Rzeczy opowiedziane osaczają nas i powracają do nas jak duchy [Lo dicho nos acecha y revisita a veces como los fantasmas] [...] ${ }^{\prime \prime}$. „Marlow nawiedza wyobraźnię czytelników Conrada, czy to was, czy mnie [Marlow haunts the imaginations of Conrad's readers, you or me ]"20, zauważa w innym kontekście J. Hillis Miller. Pozostając w obrębie tej sugestywnej obrazowości, można mówić o pracy literaturoznawcy jako laboratoryjnej analizie fikcyjnych widm ze względu na zawarte w nich spektrum poznawcze, oferujące wycinek segmentacji wielkości egzystencjalnych.

6. Literatura współczesna jawi się jako imponująca w swoim bogactwie, a zarazem w potężnym kryzysie - nie twórczym, bo nie brakuje przecież nietuzinkowych autorów, lecz recepcyjnym, bo zdaje się brakować przekonujących czy rzeczywiście działających pomysłów na praktykowanie lektury. Kryzys fikcji literackich można postrzegać jako część szerszej zmiany, w dłuższej perspektywie prowadzącej być może do dalej postępującego zastępowania ich (w większości funkcji) przez fikcje zapośredniczone przez media potęgujące doznania immersyjne. Dziś, gdy dyspozycje recepcyjne młodszych odbiorców kształtują głównie silnie wydobywające moment sprawczości (czyli tzw. ergodyczności) fikcje pozaliterackie, nawykowe zakładanie niespornej wartości literatury wydaje się pozbawione realnych podstaw. W takiej sytuacji nie tylko przekonującym, ale i użytecznym punktem wyjścia byłoby podkreślenie nie swoistych różnic - o których można i trzeba (o czym sam jestem coraz bardziej przekonany) rozmawiać później ${ }^{21}$ - lecz wspólnego dla

19 J. Marías Zakochania (2011), przeł. C. Marrodàn Casas, W. Charchalis, Sonia Draga, Katowice 2013, s. 333. Oryg. J. Marías Los enamoramientos, Debolsillo, Barcelona 2013, s. 324.

20 J. Hillis Miller O literaturze (2002), przeł. K. Hoffmann, Wydawnictwo UAM, Poznań 2014, s. 47. Oryg. J. Hillis Miller On Literature, Routledge, New York 2002, s. 43.

Kwestią dającą szczególnie do myślenia w kontekście rozróżnienia pomiędzy fikcjami literackimi i filmowymi z jednej, a growymi z drugiej strony, jest podnoszona ustawicznie zarówno przez teoretyków, jak i użytkowników (sc. czytelników, widzów oraz graczy) różnica (na wiele sposobów nazywanej) pasywności w pierwszym i aktywności w drugim przypadku, przy bliższym wglądzie okazująca się wszakże, co ciekawe, różnicą chiazmową, ponieważ o ile w przypadku (udanych artystycznie) fikcji literackich i filmowych z fazą (pozornej bądź rzeczywistej) pasywności skorelowana jest (albo może czy powinna być) następnie faza aktywności (interpretacyjnej), o tyle nawet zaawansowanym konceptualnie i wartościowym artystycznie fikcjom growym towarzyszy po fazie (pozornej bądź rzeczywistej) aktywności zazwyczaj wciąż jednak (i niewykluczone że jest to związane z warunkami sine qua non istnienia samych fikcji tego rodzaju, np., powiedzmy, „nieuniknionością predestynacji”) pasywność (interpretacyjna). Rozważmy (sine ira et studio) choćby przypadek - w trybie niewartościującym, podkreślam (zarówno lektura, jak i gra odcisnęły silne piętno na mojej wyobraźni), ale w kontekście wzmiankowanego wyżej programowego założenia „laboratoryjnej analizy fikcyjnych widm ze względu na 
fikcji literackich, filmowych i growych ewolucyjnego zaplecza. Jedną z możliwości efektywnego działania na tym polu może być wydobycie prymarnej istotności autoautoryzującego i performatywnego wymiaru fikcji niezależnie od każdorazowego medium. „Podstawowy obowiązek powieściopisarza [The novelist's primary responsibility]", pisze J. Hillis Miller, koncentrując się już na literaturze, ,jest konstatywny [is a constative one]: mówić prawdę [to tell the truth], ale ta prawdomówność ma performatywną efektywność [but this truth-telling is performatively effective]"22. Od przemyślenia konsekwencji tego rozpoznania będzie zapewne zależeć - jeśli wierzymy oczywiście, że sprawa nie jest jeszcze tak czy inaczej dawno już przesądzona - nie tylko przyszłość fikcji literackich, lecz także los literaturoznawstwa.

zawarte w nich spektrum poznawcze" - powieści The Road (2006) Cormaca McCarthy'ego i gry The Last of Us (Naughty Dog, 2013). Nie rozwijam tu dalej tej niewątpliwie nader dyskusyjnej obserwacji (wrócę do tego w innym miejscu) - i nie szukam łatwej kontrowersji, lecz notuję jedynie uderzającą mnie prawidłowość - ale szersza tematyzacja problematyczności wzmiankowanego na wstępie silnego intuicyjnego przeświadczenia odbiorców wydaje się konieczna, jeśli nie chcemy przegapić kiedyś pewnej istotnej straty. 


\section{Abstract}

\section{Arkadiusz Żychliński}

ADAM MICKIEWICZ UNIVERSITY (POZNAŃ)

Fictiograms: Elements of transformation in Contemporary Literature

This article aims to capture the current transformation in contemporary literary fiction across the world, with a particular concern for emerging formal and literary theoretical tendencies and their possible reception. The main meta-tendency seems to be a characteristic dissonance: if we accept that fictionality is a conceptional centre of literary fiction, then it can be classified into centripetal fiction and centrifugal fiction, i.e. fiction that exposes it own fictionality and fiction that camouflages it. A series of clearly recognizable strategies emerges in both cases. Żychliński proposes a preliminary analysis of these strategies.

\section{Keywords}

contemporary literature, world literature, comparative literature, literary theory, narratology, formal transformations in literature 